\title{
Underground Opposition to Wealth Creation in Churches: The Case of Catholic and Evangelical Communities of Yaounde
}

\author{
Jane Mundi Mbacham-Enow ${ }^{1,2, ~ *}$, Fidele Alain Tatou ${ }^{1,2,4}$, Sariette Batibonak ${ }^{1}$, Akindeh Nji ${ }^{1,3,4}$, \\ Wilfred Fon ${ }^{1}$, Wilfred Fon Mbacham ${ }^{1,3,4, *}$ \\ ${ }^{1}$ Faculty of Holistic Theology, The University Institute of International Development (IUDI), Yaounde, Cameroon \\ ${ }^{2}$ The HEWAMI Foundation, Yaounde, Cameroon \\ ${ }^{3}$ The Fobang Foundation, Yaounde, Cameroon \\ ${ }^{4}$ Faculty of Sciences, The Biotechnology Centre, University of Yaounde1, Yaounde, Cameroon
}

Email address:

enowjanemundi@yahoo.com (J. M. Mbacham-Enow),wfmbacham@yahoo.com (W. F. Mbacham)

${ }^{*}$ Corresponding author

\section{To cite this article:}

Jane Mundi Mbacham-Enow, Fidele Alain Tatou, Sariette Batibonak, Akindeh Nji, Wilfred Fon, Wilfred Fon Mbacham. Underground Opposition to Wealth Creation in Churches: The Case of Catholic and Evangelical Communities of Yaounde. Social Sciences.

Vol. 10, No. 3, 2021, pp. 113-118. doi: 10.11648/j.ss.20211003.15

Received: May 23, 2021; Accepted: June 7, 2021; Published: June 15, 2021

\begin{abstract}
The Babylonian System is an underground way that negatively influences the action of Christian churches in the society. "Underground opposition to wealth creation in churches: the case of catholic and evangelical communities of Yaounde" is the title of this article and answers the following research question: How can the Babylonian system be effectively invaded in the fight against poverty in churches? 631 Christians (men, women, and youths) from the 7 districts of the city of Yaounde and from different communities were questioned. Statistical processing of the data was done with Epi Info. In accordance with a Christian author, Doctor in Divinity, who had exposed the work of the Babylonian System in the church and a discussion of results, had permitted us to bring out some solutions to reverse the phenomenon to improve alleviation of poverty in churches or wealth creation in churches. $60.60 \%$ of the respondents (362 Christians) have difficulty transcribing their faith in God in other areas of life. In a subtle way the Babylonian System destroys the faith of Christians in God and upholds them. The Church and Christians must develop a radical faith in the Lord Jesus Christ that would enable them to put into practice the principles of the Kingdom of God which are the only means of exposing and defeating the Babylonian system.
\end{abstract}

Keywords: Babylonian System, Christian Church, Wealth Creation, Poverty Alleviation, Kingdom of God

\section{Introduction}

Religion is able to have positive effects on wealth creation and poverty alleviation [1]. Most Africa's poor are deeply religious. The role of the church extends beyond the material welfare of its members, and even beyond temporal concerns altogether. But there is an important area of common ground between faith and development [2]. The regulation offers a key insight into how the lawmakers see religion and what aspects of religious life they consider important $[19,20]$. The Babylonian system is the kingdom of darkness that is being governed by Satan through his demonic host and the fallen nature of the flesh. Satan used man as his tool and the earth as his springboard of operation (Ephesians 2:1-3) [7]. "The enemy wars against any church that seeks to grow for God's glory. Regrettably, he often wins battles simply because we are unprepared for the conflict [6]. The devil uses several strategies to keep human beings captive to his authority through the Babylonian system. Babylon was a powerful trope. The Apocalypse made it a symbol of all the decadence and prolificacy of the kingdoms of the earth, that wicked harlot of the world [14]. In 587 the Babylonian king Nebuchadnezzar attacked and destroyed Jerusalem and its temple, deporting many of its inhabitants to Babylon. The fall of Judah, with its utter destruction of Jerusalem and the temple, brought to an end 
political, social, and religious life in Judah. The culture shock caused by deportation, the problem of adaptation, and their resentment against God for letting it happen made this the strongest test the Jews had undergone. Their survival required nothing less than the reinvention of their identity [15]. A growing concern among religious organizations is the need for business acumen by their leaders as it is estimated that 3500 churches close each year due to inadequate management of resources [16, 17]. Approximately 350000 churches in the US are currently struggling financially and need major help to improve stability $[16,18]$. Foohey [18] asserted many reasons exist why churches struggle to survive, among appropriate management resources by church leaders. The church whose mission is to raise up the followers of Christ is being fought by the Babylonian system. Lawless [6], presents 8 ways enemy attacks churches: “(1) Congregational division: churches divided over budget decisions, paint colors, worship styles, Bible versions, community outreach, global missions, staffing choices, service times, choir robes, small group curriculum, and church vans. (2) False teaching: Small group leaders teaching unbiblical theology, with no internal system in place to recognize or address that problem, No oversight or accountability about curriculum taught in small groups, Theologically-suspect material in the literature rack, Problematic "recommended reading" in the church library, Music lyrics that promote bad theology, Poor exegesis of biblical texts. (3) Family breakdown: two believers divorcing. (4) Hidden sin: someone in church leadership had been living in sin for months, if not years, even while doing his day-to-day ministry. The Babylonian system nurses corruption, in a biblical context, the Greek word for 'corruption', diaphthora, connotes decay (Rm $8: 21)$. Corruption is a state of spiritual decay and moral dishonesty, arising from the effects of sin, which expresses itself in disobedience towards God [12, 13]. (5) Transfer growth diversion: the enemy is seldom threatened when churches grow only by "swapping sheep" with other churches down the street or across the city. (6) Self-dependence: Some churches would continue to exist for some time even if God withdrew His presence. That is, they operate in their own strength and ability, but they do it well. (7) Discipleship distraction: The enemy delights in churches that have no strategic, effective discipleship strategy. After all, these churches have no plan to teach believers how to wear the full armor of God (Eph. 6:11). (8) Hopelessness: It's easy to get here. Church leaders give all they have to give, yet with few results. The Church is dying but unwilling to change."
The Babylonian system attacks the Glory of God in the church in a subtle way. The Babylonian system divides the church, releases false teachings, destroys Christian families, leads Christian leaders to live in sin, evangelism is oriented toward Christians from other churches, several churches operate out of Divine blanket dilutes the quality of the formation of the disciples of Christ and sows discouragement in the lives of Christians. How to invade the Babylonian system for efficiency in the fight against poverty in churches is the research question of this article titled: "Underground opposition to wealth creation in churches: the case of catholic and evangelical communities of Yaounde".

\section{The Research Methodology}

The research methodology used was the survey method. This researcher from a doctoral dissertation [3], constructed and administered questionnaires to 631 Christian from all the 7 districts that make up the City of Yaounde. Congregational studies provide a qualitative and quantitative approach to data collection through questionnaires that evaluate the church with a multidisciplinary approach, Hartford Seminary [4]. The evaluation of the level of poverty in the Church was carried out on two fronts: faithfuls, in relation to their local church on the one hand and the role of the church on the other. The following aspects were evaluated: the functional role of the church, the organizational role of the church and the identity role of the Church. Proportional analysis of the data was done with Epi Info. The book of Nwaka [8], entitled "Invading the Babylonian System", had exposed the work of that system in the church and a discussion of results had permitted us to bring out some solution to reverse the phenomenon to improve alleviation of poverty in churches.

\section{The Research Results}

\subsection{Position of Christians on Certain Christian Values}

The disagreement with the following belief statements is strongly influenced by the doctrinal values. Calling into question the total or partial Christian values could be a source of spiritual poverty with direct repercussions on material poverty, suggesting either a lack of adequate biblical teaching or deliberate refusal of the Christian to align to these Christian values.

Table 1. Agreement with the following belief statements.

\begin{tabular}{ll}
\hline Belief statements & Agree and Strongly Agree \\
\cline { 2 - 2 } & Frequency \\
\hline 1. There is no other way to salvation but through belief in Jesus Christ & 574 \\
2. The Bible has answers for all of the basic questions of life & 573 \\
3. It is often difficult to live out my faith in daily work, leisure and community life & 362 \\
4. Jesus' resurrection from the dead was actual event & 563 \\
5. Human beings have developed over millions of years from less advanced forms of life & 185 \\
6. All religions are equally good ways of helping a person find ultimate truth & 217 \\
7. Social justice is at the heart of the Gospel & $396,10 \%$ \\
\hline
\end{tabular}

Source: Enow (Field Survey, 2016) 


\subsection{Christian Disagreement with the Following Belief Statements}

Figure 1 shows the Christian disagreement with the following belief statements.
185 respondents out of the 631 Christian put to question the fact that God is the creator of human beings. 362 respondents have difficulty transcribing their faith in God in other areas of life.

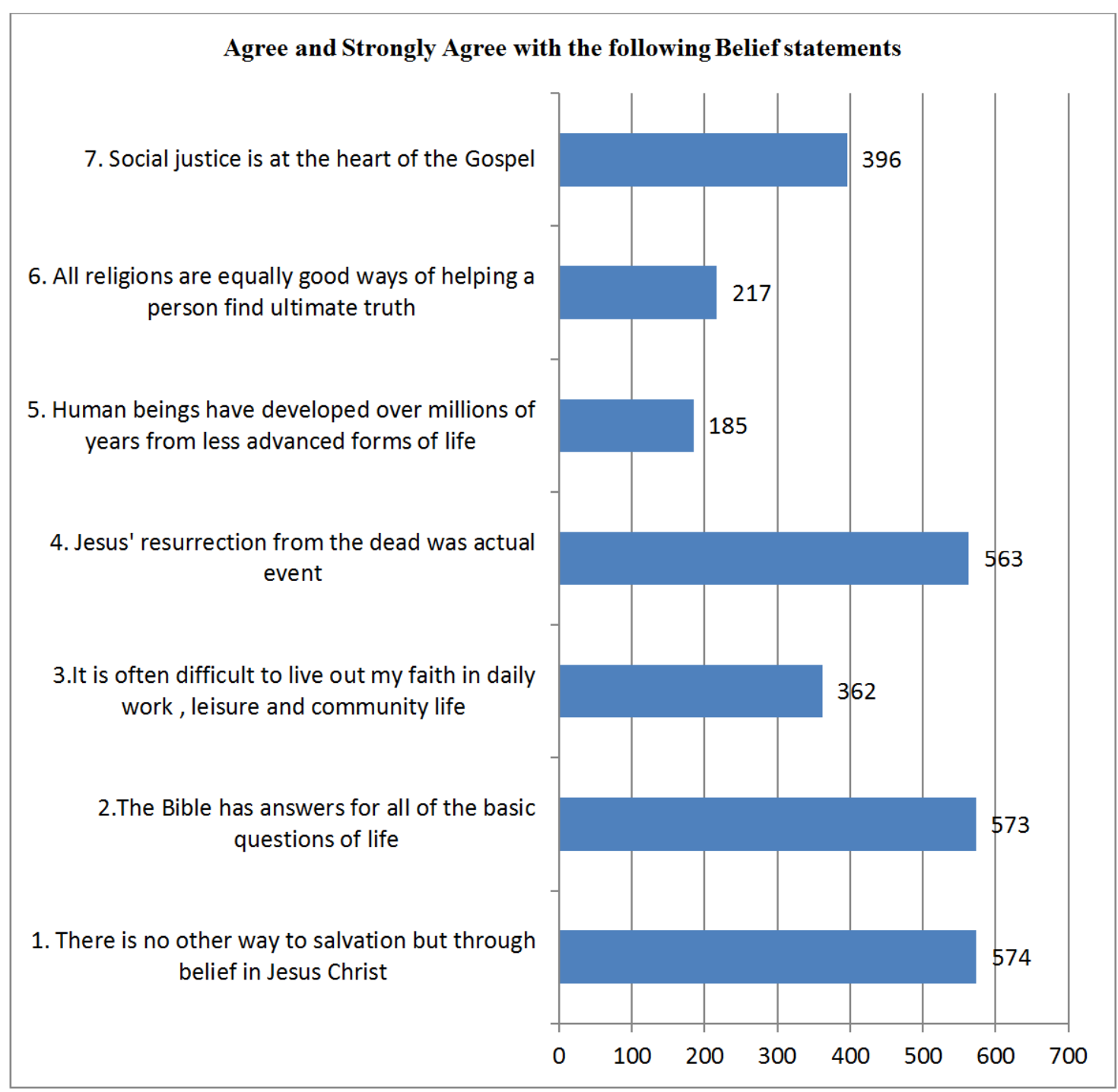

Source: Enow (Field Survey, 2016)

Figure 1. Agreement with the following belief statements.

\section{The Research Discussion}

The Babylonian system according to Nwaka [8], is the system that impoverishes the Christian church. Several authors support Nwaka's [8], remarks, including Winter [9], who has researched the history of Christian movements and divided them into ten eras. The present period between the years 1600 and 2000 years after the death of Christ is the period which he describes as the period of the end of the earth. The Bible speaks of the signs that will precede the end of time. These signs are: difficult times, human beings will be egoistic, friends of money, braggarts, lofty, blasphemous, rebellious to their parents, ungrateful, irreligious, insensitive, disloyal, slanderous, intemperate, cruel, enemies of people (2 Tim. 3: 1-5). This was the first time that God had given him the name of God. In other words, the Babylonian system subtly destroys the faith of the believers. That is why Jesus Christ asked the question: would He find faith when He comes back? (Luke 18: 8). Remember, as the Bible says, without faith it is impossible to please God (Heb. 11: 6) and consequently condemns remaining poor.

The eight reasons presented by Nwaka [8], to explain how the Babylonian system works will help us to find possible solutions to make the Church effective in the fight against poverty. 


\subsection{The Babylonian System Works to Impoverish the Church}

"The church especially in Africa is expected by society to be poor. Whenever a church or a pastor has wealth of any sort, it is always scrutinized by society very critically. Similarly, well-meaning Christians can give huge amounts of money to charities and other causes but will find it hard to give the same amounts of money to the church. If a church turns out to be wealthy, people are uncomfortable with this idea. When a pastor or a Christian Brother or sister obtains massive wealth majority of the people will question it. It is normal for a pop musician to own two or three jet liners but if a pastor or Christian brother owns a modern, expensive vehicle, it does not sit well with society. The Babylonian system works to make the righteous poor and present them in light of neediness and poverty." [8].

The Babylonian system nourishes the mentality of society to consider the church as a place of poverty and lack. This way of thinking slowed down the conversion of many unbelievers who are afraid of becoming poor Christians materially.

Christians give very little of their offerings to the church led by the Babylonian system, and this state of things could also explain why Christians are poor and remain in poverty.

In agreement with Krejcir [5], a church growth specialist who says church leaders are sometimes afraid to teach Christians about financial stewardship. This declaration demonstrates the action of the Babylonian system which influences the perception of the church by Christians as a place of poverty and consequently teaching on the contrary would bring strong opposition from Christians who call church leaders to manifest covetousness of money. Not to teach about financial stewardship, the church would encourage Christians to remain in poverty.

The church has the duty to build strong givers and also to lay bare any usurper who would marry the Christians with the gospel of prosperity. In other words, we must change the minds of Christians on the action of the Babylonian system by the contribution of false doctrines (Rom. 12: 1-2) and do it under the guidance of the Holy Spirit because instead of solving the problem of poverty, some Christians would find themselves betrayed, robbed, stripped,...; (John 10: 10a).

\subsection{The Babylonian System Uses Only the Best}

"Today there is a lot of competition when aspiring for elite jobs. People aim for certain jobs which are lucrative and those are quite few. Studying, working very hard, trying to improve oneself in every area of life has become the trend for today. It was not just Daniel and his friends in the Bible who were found to be 10 times better than all the other youths under royal training; today believers are among the best brains in society. The Babylonian system demands the best in everything. You are not only required to be intelligent or talented in your work, but you get more mileage in the system when you are considered physically beautiful, very youthful and have other redeeming qualities to add to your resume. All the competition that has been borne today is so that someone is able to fit into this system and excel in it." [8],

The Babylonian system just fulfills the mission of the devil: to kill, to steal and to destroy (Jn. 10: 10a) or use seduction and oppression to destroy human beings (Rev. 6: 2-8).

The Babylonian system uses oppression to prevent Christians from getting good jobs or getting married. The Babylonian system deprives the Christians of the fact that they have the right to be compromised by the bias of seduction if they wish to enjoy the benefits that are theirs.

The church because of the Babylonian system is filled with spiritual deaths, which explains all the challenges faced by the church.

The church and the Christians must face all forms of persecution under the guidance of the Holy Spirit (Lk. 12:12).

\subsection{The Babylonian System Disregards the Poor}

"The Babylonian system has a 'sell-by date' for people whom it takes in. Everyone is dispensable and disposable in the system. It does not matter how intelligent, gifted, or useful one has been. The minute you become slower, old or sick, you become a liability. The Babylonian system brooks no liabilities. It is a profit-making machinery through and through. It does not accept any slackness.” [8],

The Babylonian system calls into question the spiritual values of the church, including the care of the needy. In other words, the Babylonian system takes charge of putting every productive person to work and rejects any less privileged person, or the Babylonian system bypasses the values of human beings to serve their system after exhausting and are rejected. This can demonstrate why society just like the church is overloaded with many destitute.

The church must lead the Christian to make the difference between secular work and spiritual commitments. The absenteeism of Christians is remarkable in the church because the majority of the time is used in the secular activities to the detriment of those of the church. The church must educate the Christian on the place of his Christian faith in society, how to interact with church and society (Table 1, line 3). Failing to do so would leave Christians and non-believers in the mercy of the Babylonian system which will exploit them to the point of rendering them useless. On the other hand, every Christian needs to develop and deepen his relationship with God, to highlight his/her spiritual gifts so that he/she can free himself/herself from the trap of the Babylonian system. In other words, any Christian who refuses to grow spiritually on a daily and permanent basis may find himself/herself in the grip of the Babylonian system.

The Church must limit by all its strengths the action of the Babylonian system to multiply the poor in society by an action upstream, stop the actions of the Babylonian system and downstream bring the restoration by the Lord Jesus Christ to the victim of the Babylonian system.

\subsection{The Babylonian System Renders the Church Obsolete}

"The Babylonian system takes biblical principles that it 
considers useful to its development and disregards the rest as negotiable or sometimes, irrelevant principles." [8].

The Babylonian system is aware of the fact that the Bible is the Word of God that should guide every Christian (Josh. 1: 8), and is therefore responsible for sowing doubt in the understanding of the Word of God. The Babylonian system knows that the knowledge of the Word of God by the Christian frees him/her from sin, from all forms of slavery (Jn. 8: 31-32), and from the ignorance that causes Christians to die (Hos. 4: 6).

The use of the Bible by some church leaders for personal purposes and not for the glory of God. This way of acting is subtly induced by the Babylonian system which detours the church leaders from their mission of framing the people of God in accordance with the Word of God, consequence: Christians are poorly nourished spiritually therefore poor (Table 1).

Many respondents perceive the Bible as follows: The Bible is the inspired Word of God and its basic moral and religious teachings are clear and true, even if it reflects some error. When the Christian recognizes God as the author of the Bible and speaks of errors therein, it shows that the Babylonian system would be feeding the thought of Christians to look at the Bible in a human dimension to the detriment of its Divine dimension, consequence: the Christian remains imprisoned in the poverty.

The Babylonian system still at work in this case to distract Christians from the spiritual activities that can lead them to know the Word of God and free themselves from the devices of this satanic system.

The Church and all Christians should make it a point of honor to discover the Bible daily and continuously under the guidance of the Holy Spirit (Rom. 14: 8) to discern what is good, pleasant and perfect (Rom. 12: 1-2).

\subsection{The Babylonian System Destroys Identity of the Church}

«Once the church has no voice, it is considered irrelevant, unqualified and incompetent. When this happens, the only way the church will find identity within the Babylonian system is to conform to what the system dictates to it. The church loses its own identity as the barometer that measures the moral temperature of the nation. It loses its identity as an ambassador of Christ and can therefore not influence the place where God has sent it.» [8],

The Babylonian system persecutes the church to force it to follow its standards to lead it to compromise God's standards. The Babylonian system does not want Christians to worship God in spirit and truth as recommended by the Word of God (Jn. 4: 23-24).

Many Christians under the Babylonian system go to church looking for other interests than worshiping God (2 Tim. 3: 1-5). The Babylonian system leads some church leaders to seduce and oppress Christians with illusory miracles that tarnish the image of the Church and destroy faith in God of human beings.

Jesus came with grace and truth (John 1:14), which the church and every Christian have a mission to spread throughout the world (Matthew 28: 18-20).

\subsection{The Cornerstone of the Babylonian System Is Spiritual Idolatry}

"Many leaders publicly own up to consulting mediums, witchdoctors and sorcerers for leadership. Many senators and governors in the USA and Europe are involved in secret occult organizations that do not worship God but draw power from the kingdom of darkness" [8].

Jesus Christ is the cornerstone (Acts 4:11) on which every human being should rely to succeed in all areas of life. The Babylonian system offers human beings spiritual idols as the cornerstone.

Challenging the fact that Jesus is the only way of salvation could be an open door in the Christian's life to resort to the Babylonian system (Table 1). Christians recognize in many their inability to live their faith in all areas of life, the difficulty for the Christian to translate his/her faith into secular activities would make him/her vulnerable and easy to compromise with the Babylonian system (Table 1). When Christians seek social justice outside the Word of God, Christians are at risk of resorting to the idols offered by the Babylonian system.

The church should encourage all its Christians to be present in all areas of social life. The absence of Christians in secular circles gives much room to the Babylonian system, which infiltrates the church and tries to weaken the impact of the church on Christians and on society.

\subsection{The Babylonian System Withholds Strategic Positions from the Righteous}

"The system works to make sure the righteous do not occupy strategic positions in strategic institutions. If it is a working place, Christians tend to have lower positions or managerial positions that are not strategically decision making ones. If you are in government it will be difficult to get appointed into strategic institutions" [8],

The goal of the Babylonian system is to frustrate Christians professionally in order to get them to compromise and solicit this system to be promoted or occupy the positions they deserve. Every Christian must understand that their intrusive value is not limited to the appreciation of human beings but to the gifts and talents deposited by God in them. Christians must all discover and develop their gifts and talents so as not to be influenced by social injustice. Every Christian has to know what value he/she has before God and to do his/her best to do his/her work as if he were doing it to God (Col. 3:23). The God of righteousness will take charge of him/her at the proper time to raise $\mathrm{him} / \mathrm{her}$.

The Christian is challenged to be patient and to serve well in a constant manner whether in church or in other areas of life. Impatience is an open door in the life of the Christian to resort to the harmful proposals of the Babylonian System.

\subsection{How Has the Church Gone Wrong}

"There is something wrong with the mindset of the church today. The church leaders have preached the church and denominations but not the kingdom. " [8], Christian churches have in common God the Father, God the Son, God the Holy 
Spirit and should work as the body of Christ for the Kingdom of God.

The absence of the mentality of the Kingdom of God manifests itself in the barriers that exist between Christian churches due to denominational differences. It becomes difficult for churches and Christians to be united in the struggle against the Babylonian system. The development of teachings that preach denomination to the detriment of the values of the Kingdom of God leads some Christian communities to radically oppose other Christian churches. The mentality of the Kingdom which perceives the church as the body of Christ would be the key to halting or limiting the effects of the Babylonian system in the church and in society.

Religion can strengthen the resilience of individuals and entire societies because it offers explanations and rituals that help people deal with loss, suffering, failure and disaster. Religion can give people a sense of identity and bring people together in the same way that it can also be used to exclude people. Religion can also be exploited in order to safeguard one's position of power, suppress critical voices and avoid democratic reforms [10, 11]. Nwaka [8], Doctor of Divinity, exposes the devil's mute action through the Babylonian system whose mission is to maintain the church and Christians in poverty. It should be noted that the action taken by the Babylonian nation to maintain the People of God in captivity in the book of Daniel in the Bible are still current. How to invade the Babylonian system for efficiency in the fight against poverty in churches is the research question of this article titled: "Underground opposition to wealth creation in churches: the case of catholic and evangelical communities of Yaounde". 631 Christians (men, women, and youths) from the 7 districts of the city of Yaounde and from different communities were questioned to evaluate their involvement as faithfuls with their local church in terms of stability, regularity, responsibility and feeling at ease [3]. The results obtained in this document demonstrate the underground action of the Babylonian system by the conduct of Christians to reject the fundamental values of faith in God: $60.60 \%$ of the respondents (362 Christians) have difficulty transcribing their faith in God in other areas of life and 185 respondents out of the 631 Christian put to question the fact that God is the creator of human beings. The discussion of these results exposes the action of the Babylonian system on two axes: to nourish the incredulity of the Christians and, on the other hand, to encourage the church leaders to dilute their teachings on the Word of God. The Church and Christians must develop a radical faith in the Lord Jesus Christ that would enable them to put into practice the principles of the Kingdom of God which are the only means of exposing and defeating the Babylonian system.

\section{References}

[1] Badee, H. An Inquiry on the Role of Religion in Wealth and Poverty.

[2] Belshaw, D. G. R., Calderisi, R., \& Sugden, C. (Eds.). (2001). Faith in development: Partnership between the World Bank and the churches of Africa. World Bank Publications.

[3] Enow M. M. J. (2019). The fight against poverty in churches: an examination of Catholic and Evangelical communities in Yaounde. IUDI, PhD Thesis in Systematic Theology.

[4] Hartford Seminary, Hartford Institute for Religion Research (2000 - 2015). Congregational Assessment Inventories. Retrieved from http://hirr.hartsem.edu/leadership/church_inventory.html.

[5] Krejcir R. J. (2000). 44 Church Growth Principles that are Real and Work! Retrived from http://www.intothyword.org/apps/articles/default.asp?articleid $=32791$.

[6] Lawless, C. (2002). Discipled warriors. Grand Rapids: Kregel.

[7] New International Version (NIV). Holy Bible, New International Version ${ }^{\circledR}$, NIV ${ }^{\circledR}$ Copyright $\mathbb{C} 1973$, 1978, 1984, 2011 by Biblica, Inc. ${ }^{\circledR}$ Used by permission. All rights reserved worldwide. Retrieved from https://www.biblegateway.com.

[8] Nwaka, B. (2007). Invading the Babylonian System. Lusaka: Campus Voice Publishers.

[9] Winter, R. D. (1981). The kingdom strikes back: The ten epochs of redemptive history. Mission Frontiers Book Service.

[10] Anim, E. K. (2020). An evaluation of Pentecostal Churches as agents of sustainable development in Africa: The case of the Church of Pentecost. In African Initiated Christianity and the Decolonisation of Development (pp. 195-211). Routledge.

[11] BMZ. 2016. Religious Communities as Partners for Development Cooperation. Berlin: Bundesministerium für wirtschaftliche Zusammenarbeit und Entwicklung.

[12] Coetzee, W. \& Snell, L. E., 2013, A practical-theological perspective on corruption: Towards a solution-based approach in practice, viewed 13 May 2017.

[13] Asea, W. B. (2018). Combating political and bureaucratic corruption in Uganda: Colossal challenges for the church and the citizens. HTS Theological Studies, 74 (2), 1-14.

[14] Herrmann, E. (2020). The Babylonian Captivity (1520). Lutheran Quarterly, 34 (1), 71-81.

[15] Kappelle, R. P. V. (2018). The New Creation: Church History Made Accessible, Relevant, and Personal. Wipf and Stock Publishers.

[16] Bayton, R. J. (2020). Business and Finance Education for Christian Church Leaders: A Qualitative Study (Doctoral dissertation, Northcentral University).

[17] Stetzer, E. (2013). The State of the Church in America: Hint: It's Not Dying. Christianity Today, 1.

[18] Foohey, P. (2015). When Faith Falls Short: Bankruptcy Decisions of Churches. Ohio St. LJ, 76, 1319.

[19] DuBois, Thomas David. 2017. China's Religion Law and the Perils of Counting Consciousness. In Disturbances in Heaven. Edited by Ivan Franceschini, Kevin Lin and Nicholas Loubere. Canberra: ANU Press, pp. 92-97.

[20] Masláková, M., \& Satorová, A. (2019). The Catholic Church in Contemporary China: How Does the New Regulation on Religious Affairs Influence the Catholic Church?. Religions, $10(7), 446$. 